\title{
Epistemology and Language in Indian Astronomy and Mathematics
}

\section{Roddam Narasimha}

Published online: 19 June 2008

(C) Springer Science+Business Media B.V. 2008

\section{Erratum to: J Indian Philos (2007) 35:521-541 DOI 10.1007/s10781-007-9033-5}

The following changes should be inserted to improve the quality of this article

\begin{tabular}{|c|c|c|}
\hline Sl. No. & Location & As corrected \\
\hline 1. & p. $524,11.18,19$ & $\begin{array}{l}\text {. . down the table in the order } \\
\text { in which a new pramāna is added } \\
\text { to the previous entries. }\end{array}$ \\
\hline 2. & Table 1 , Heading & $\begin{array}{l}\text { Table 1. Pramāṇas in Indian } \\
\text { philosophical systems }\end{array}$ \\
\hline 3. & p. $526,1.16$ & $\begin{array}{l}\text { inference after understanding } \\
\text { trustworthy testimony }\end{array}$ \\
\hline 4. & p. 536, Table 2 , line 10 , col. 2 & Replace A1 by ${ }_{1}^{\mathrm{A}}$ \\
\hline 5. & p. 536 , Table 2 , lines $12-14$, col. 2 & Replace ${ }_{\mathrm{B}}^{\mathrm{A}}$ by $\underset{\mathrm{B}}{\mathrm{A}}$ \\
\hline 6. & p. 537, below (2) & $\ldots x=20$ \\
\hline
\end{tabular}

The online version of the original article can be found under doi: 10.1007/s10781-007-9033-5.

R. Narasimha $(\bowtie)$

Jawaharlal Nehru Centre for Advanced Scientific Research/National Institute of Advanced Studies, Jakkur,

Bangalore, India

e-mail: roddam@caos.iisc.ernet.in 